\title{
Survival and Dysfunctions of Bureaucracy: A Critical Analysis of Public Bureaucracy in Sri Lanka
}

\author{
Mohamed Ibrahim Mohamed Irfan \\ Faculty of Islamic Studies and Arabic Language, South Eastern Universitry, Oluvil, Sri Lanka
}

Email address:

irfanibrahim86@gmail.com

\section{To cite this article:}

Mohamed Ibrahim Mohamed Irfan. Survival and Dysfunctions of Bureaucracy: A Critical Analysis of Public Bureaucracy in Sri Lanka. Advances in Sciences and Humanities. Vol. 2, No. 4, 2016, pp. 31-39. doi: 10.11648/j.ash.20160204.11

Received: October 19, 2016; Accepted: November 1, 2016; Published: November 25, 2016

\begin{abstract}
This study examines the survival and dysfunctions of public bureaucracy in Sri Lanka. Major objective of this study is to analysis functions and practical challenges of public bureaucracy in Sri Lanka. As well as it tries to find out the solutions which can be used to improve the effectiveness service of bureaucracy in Sri Lanka. Bureaucracy is most important role in the world: implementation and formulation of policy, delegated legislation, administrative adjudication, importance to government and governing process, service to the people, etc. In contrast, it has earned a nick name for red tapism, nepotism, and corruption. This study is a qualitative research and data were collected mainly from secondary sources such as books, journals, newspapers, internet articles and relevant research articles. In Sri Lanka, public bureaucracy has earned bad name and ill will of the people, due to challenges of Public Administration Reforms (PAR), inefficiency and ineffectiveness public service delivery, dysfunction of constitutional arrangements, ineffectiveness of Public Service Commission (PSC) and ombudsman, failure and changing the public policies, politicization and family rule of administration, ethnic, regional vise bureaucracy, insufficient resources and capacity, lack of citizen participation and lack of awareness of the citizens, corruption etc. Ensuring provincial autonomy decentralization, ensuring greater communication and accountability between policymakers, citizens, bureaucrats and politicians, ensuring higher salary scale/higher salaries in public sector, strengthening stakeholders and citizen participation, strengthening the Public Private Partnership (PPP), introducing e-government techniques and New Public Management (NPM) reform in governance process, administrators should learn and get the training in other languages (Tamil and Sinhala), strengthening the ombudsman and public service commission and ensuring better financial management and accountability are can be improving public bureaucracy in Sri Lanka.
\end{abstract}

Keywords: Bureaucracy, Dysfunction, Survival, Sri Lanka

\section{Introduction}

\subsection{Meaning of Bureaucracy}

Bureaucracy is the sovereign factor in public administration. It should be characterized by the societal make-up in order to ensure democracy in the administration. It has wider meaning such as it deals with classification, recruitment promotion compensation, discipline, retirement benefits of the personnel in government, and so on. According to Encyclopedia of Britannica, Bureaucracy is "a body of professional, full time officials employed in the civil affairs of a state in non-political capacity" [13]. It is a professional body of officials, permanent paid and skilled. The requirements of the civil service are that it shall be impartially selected, administratively competent, politically neutral and imbibed with the service to the community.

Bureaucracy is a government on desk and quite prevalent in many parts of the world. The term has however, earned disreputation for red tapism, nepotism, and routine. It is a government of trained persons and brought up for running the administration which means that, it is a body of public servants organized in a hierarchical system (outside the sphere of effective public control).

The father of the bureaucracy, Max Weber also argued that the bureaucratization of the modern world has led to its depersonalization. Hierarchy, Regimentation and Specialization were practiced as early as 10,000 years ago during the agrarian period resulting in a triangular shape social structure. Gradually, bureaucracy started being 
practiced in every sphere of life and became universal due to its efficient and organized structure. However, from the last four decades bureaucracy is not up to snuff in public institutions and governmental settings properly and it is believed that rapid growth in global development is one of the reason [5]. Max Weber who had systematically theorized (ideal) bureaucracy for the first time, he is a notable German sociologist, political economist, and administrative scholar, who contributed to the study of bureaucracy, administrative discourses, and literature during the mid-1800s and early 1900s. Weber described many ideal types of public administration and governance. His critical study of the bureaucratization of society was one of the most enduring parts of this work.

Characteristics of bureaucracy are namely, it follows a hierarchical system, it runs on the principal of political neutrality and, impartiality, it brought up and developed with the object of running of administration, bureaucrat person is supposed to strictly follow rules and regulation, and so on. Different writers have tried to discuss characteristics and salient features of bureaucracy in their own way. According to Friedrich these features include hierarchy, discipline, objectively, certain minimum qualification, continuity, red tape and discretion. Robert K. Merton believes that bureaucracy means, reliability, devotion and adoption [15]. According to Max Weber, bureaucracies have number of key characteristics that make their resemblance to beehives all the more apparent such as there is a clear hierarchy of officials, the function of the official are clearly specified, officials are appointed on the basis of a contract, there are selected on the basis of a professional qualifications, they have money salary, and usually pension rights, the official's post is his sole or major occupation, there is a career structure and promotion, a division of labour, a set of formal rule [1].

\subsection{History of Sri Lanka's Bureaucracy}

Sri Lanka had been practicing a feudal type of bureaucracy until it fell into the hands of the Western imperialism. From the beginning of the $16^{\text {th }}$ century to the mid- $20^{\text {th }}$ century, the country was ruled by the Portuguese, the Dutch and the British. However, some considerable administrative changes which influenced the structure of the present civil service practices took place in the British Colonial period.

The first constitutional reform to Ceylon, the Colebrook proposal of 1833 established the Ceylon Civil Service introducing an autocracy to bureaucracy. In 1833, the entire country was divided into five provinces, each was placed under a government agent (GA) and the provinces were subdivided into district, each under an assistant government agent (AGA). Then after, constitutional reforms of 1912, 1920 and 1924 added considerable changes to the Civil Service. By 1928, the de-concentrated administrative structure headed by the colonial secretary through the GAs consisted of nine provinces and districts, 110 chief headmen's divisions, 613 subdivisions under the headmen, and about 4000 village under village headmen [21]. The Donoughmore reforms of 1931 contributed to major civil service reforms expanding and demarcating bureaucratic functions following universal suffrage. Later in 1947, the Soulbury reforms were introduced, but it did not aim to reform the colonial structure or ideology of the Civil Service, in 1963, the government abolished the Ceylon Civil Service. In 1972, when the first republican constitution was adopted, removing all constitutional links to the British System. In 1978, the second republic constitution has introduced with the executive president system. In 1987, 13th amendment (Provincial Councils) was introduced after military intervention by Indo-Sri Lanka agreement. It is also being considered as sub-national governments in the Island. The PCs are legislative bodies of the nine Provinces of Sri Lanka.

The administrative structure of the country was highly centralized and more focused on process rather than on outcome because of the British Influenced. But, practically public administration decentralized such as Provincial Councils-09, District Secretariat-25, Divisional Secretariat332, and village level (Grama Niladhari (GN) divisions14054). As well as Sri Lanka has been adopted 23 Municipal Councils, 41 Urban Councils and 271Pradeshiya Sabhas.

In this context, bureaucracy is most vital role in the world: implementation and formulation of policy, delegated legislation, administrative adjudication, importance to government and governing process, service to the people etc. but it has earned several bad name such as a nick name for red tapism, corruption, politicization etc. specially developing countries such Sri Lanka. Therefore this study tries to analysis survival and dysfunctions of public bureaucracy in Sri Lanka. And it further explores the solutions which can be used to improve the effectiveness service of bureaucracy in Sri Lanka.

\section{Theoretical Analysis}

An organization has ever been existed without any form of bureaucracy. One of the most important thinkers in bureaucratic theory, Max Weber (1864-1920), is the father of the bureaucratic management theory. Weber was a German sociologist and political economist that viewed bureaucracy in a positive light, believing it to be more rational and efficient than its historical predecessors. Weber first describes the concept of bureaucracy an ideal form of organizational structure. Weber states, Authority is principally exemplified within organizations by the process of control. He has identified three sources of legitimacy authority namely, traditional, charismatic and rational legal. Bureaucracy is the universal and most progressive and modern from organization, which is based on rational legal authority.

Functionalist theory is largely attributed to Robert Merton; it has written basically as a critique of Weberian ideal type bureaucracy, he had bring about his theory of bureaucracy from the functional perspective. Moreover, administration excessive dependence on hierarchy, impersonality and so on, bureaucracy as a service will degenerate into a dysfunctional organization [1]. Merton's contribution to sociology is one of 
grade importance in a functional perspective in a society. He has recognized some functions were intentional and other functions were not. He also acknowledge with some function actually disrupted society. According to functionalism, society is a system of interconnected parts that work together in harmony to maintain a state of balance and social equilibrium for the whole [16]. He has identified three types of functions: Manifest functions (consequences that are intended and commonly recognized), Latent functions (consequences that are unintended and often hidden) and Dysfunctions. Dysfunctions can also be manifest or latent. Manifest dysfunction of a social event like festivals could include traffic jams, closed streets, and piles of garbage. A latent dysfunction may include people absenting themselves from work after the event to recover. Robert K. Merton developed a middle-range theory for the study of bureaucratic organizations which explains a manageable set of relations rather than the broad-gauge special theories at one extreme, and non-comparable individual cases on the other [20].

A group of theories criticized bureaucratic phenomenon as pathological. The pathological pattern in bureaucracy has been identified as a typical sickness. Victor Thompson has explained the nature of pathological pattern in bureaucracy or 'bureau pathology' [1]. The post bureaucratic theory mesmerize up a change of a new organization reality informed with temporary work system. Therefore, the traditional structure of bureaucracy fails to cope with the new organization reality. Warren Bennis was one of the chief proponents of the post bureaucratic theory. According to him, bureaucracy should followed managerial practice follow as: leaders lead by pulling rather than pushing, by inspiring rather than ordering, from bureaucracy to flexible adhocracy, centralization replaced to decentralization, authority based influence to expertise based influence and so on. Bannis has identified some relevant threats to bureaucracy such as: rapid and unexpected change, complexity of modern technology and psychological threats [1].

\section{Methodology}

In order to examine the survival and dysfunctions of public bureaucracy, this study uses the empirical evidence to analysis functions and practical challenges observed in Sri Lanka. This study is a qualitative research and data were collected mainly from secondary sources. This paper critically analyzed published research in the forms of books, academic journals, newspapers, government related report, internet articles and relevant research articles.

\section{Results and Discussion}

\subsection{Survival of Public Bureaucracy in Sri Lanka}

The bureaucratic are most important role in third world countries such as implementation of policy, formulation of policy, delegated legislation, administrative adjudication, and so on. In addition to the above, the bureaucracy also performs the following functions: Administrative planning, handling financial operations of the stat reforming and improving administration and public relations. In the case of Sri Lanka, there are four levels within which bureaucratic institutions function such as the central, provincial, district and divisional levels, village level bureaucracy too could be included as there are multifarious functions performed by officials working at this level. Therefore the emphasis on economic and social development has given a new dimension to all public administrative institutions [26]. Thus we can say that, the bureaucratic organizations, which exercise both power and influence, contribute to the making and implementation of policy, and this has been the significance of bureaucratic power. The policy context, the civil service and servants, the policy making process with emphasis on policy implementation, evaluation of the public bureaucracy's role or characteristics of policy implementation.

According to Warnapala (2013) argue that, Sri Lankan bureaucracy system have to adopt the following perspectives such as: historical description of actors and processes in public administration, problems of devolution of power and its impact on public administrative institutions, the existing institutional arrangement, emphasizing on such issues as coordination, problems of control, accountability, performance and measurement of efficiency, use of the case study method to understand specific community issues, biographies of key administrators who have played a significant role in the public administration of the country, central, provincial, district, divisional and village level administrative institutions and their respective relations with the institutions in the administrative state and politicisation of the bureaucracy [26].

In Sri Lanka, all administrative institutions, unlike during the colonial times, are engaged in development tasks and what is required to do is to examine through scholarly research whether this function has been fruitfully achieved. For instance, the objectives of all Governments in the past have been planned development, alleviation of poverty and the extension of social welfare [26].

In Brief, the Government of Sri Lanka run through the functions of bureaucracy, It has serve the people according to the welfare state system, It has prevents the people from inequality, every bureaucratic organization has the translation officer, It has tries to introduce e-governing system and New Public Management (NPM), It trains the newly appointed bureaucrats for the particular period, provincial, districts, divisions, village level bureaucracies decentralize authority such as Provincial Councils-09, District Secretariat-25, Divisional Secretariat-332, and village level (Grama Niladhari (GN) divisions-14054). As well as Sri Lanka has been adopted 23 Municipal Councils, 41 Urban Councils and 271Pradeshiya Sabhas (Village level authorities). And also most of the bureaucrats selected by the competitive examination. Thus we can say that, the function of bureaucracy vital factor in government and governance process in Sri Lanka. 


\subsection{Dysfunctions of Public Bureaucracy in Sri Lanka}

Bureaucracy produces a number of unintended consequences or dysfunctions. Thus, the bureaucratic model has been criticized on a number of ways. It has been characterized as 'machine theory' and closed system model, which mean that, they over concerns with the formal structure of organization and neglecting the environmental factors. And also critics follow as: rigidity, static, inflexible, resistance to change and so on. In brief, bureaucracy has earned bad name and ill will of the people and it has earned a nick name for red tapism, nepotism, and corruption. Following are the major aspects of dysfunctions of public bureaucracy in Sri Lanka.

\subsubsection{Challenges of Public Administration Reforms (PAR)}

Public Administration Reform (PAR) perceives the citizen as a customer of public services and help to increase efficiency and accountability. In Sri Lanka, after independent there have been many attempts at Public Administration Reform (PAR), but lack of political commitment, resistance from within the civil service, and the absence of permanent institutional settings to establish the reform process were considered the main reasons for PAR failures. New Public Management (NPM) reform is considered as one of the best bureaucratic modal because NPM concept of perceiving the citizen as a customer of public services and help to increase efficiency and accountability. A key feature of the NPM is the concept of NPM shifts the emphasis from traditional public administration to public management, pushing the state towards 'managerialism', as well as apparently being replaced by a market-based public service management or enterprise culture [6]. Some scholars were described of NPM different terms such as managerialism, market-based public administration, entrepreneurial government, and private sector management practices. NPM essentially implies fundamental changes to the power relationships between the key players in the system of government and requires considerable attitudinal changes on the part of bureaucrats [22].

One of the prominent concerns of NPM is improving practices and techniques of personnel management system which are practiced in the Civil Service at present. NPM has shown six requirements for a better human resource capacity building in Civil Service services: adequate budgetary allocations for capacity building activities, adequate funding for training institutions, institutional relations between public sector training institutions, public-private partnership and stakeholder consultations [6].

The emphasis on better service and good governance through competition was recognised in Sri Lanka back in the 1980s. We introduced some elements of the NPM model when we were in power (1977-1994) not as a radical reform but as an incremental change [22]. Administrative Reform Committee (ARC) was appointed in the early 1980s, and it issued several interim urging the government to introduce NPM oriented reform into the public sector to cope with the emerging new situation [21].

Sri Lanka has made attempts to implement a range of NPM, but it has been facing many challenges. The following challenges also impact on the public bureaucracy in Sri Lanka such as:

- NPM reform depend on the 'Good Will' of politicians and bureaucrats, but in Sri Lanka, lack of politicians support rather than high degree of politicization of the bureaucracy. It has been major barrier to the smooth function of NPM reform.

- Lack of reliable and valid performance evolution system in the public sector.

- Red tapism, corruption and absent of rule based government.

- Lack of Public Private Partnership (PPP).

- Lack of interpersonal, communication skill and IT knowledge.

- Lack of quality of bureaucrats in local level.

- Lack of coordination between levels of governments (National to Village level).

- Week government instrument and lack of support of service providers (bureaucrats) and civil society, protests of the trade union.

Similarly, e-governance (using Information and Communication Technology (ICT) Tools) can yield great benefits in the reform and modernization of the public sector. e-Governance can also promote good governance and improving service quality. Numbers of developed and developing countries are using ICT for service delivery. In context of Sri Lanka, there introduced some elements of ICT tools service, but it has facing many challenges to implementation such as lack of ICT knowledge and technology and low rate of computer literacy among the citizens.

\subsubsection{Inefficiency and Ineffectiveness Public Service Delivery}

Public service delivery takes part a major aspect in developed and developing countries. It is makes a close relationship between the bureaucratic and citizens. The principles of public service delivery are efficiency, effectiveness and equity. Public bureaucracy is that segment of society, embraced by national, state, provincial, and local governments. According to UNDP (1999), service delivery is a set of institutional arrangements adopted by the government to provide public goods and services to its citizens [25] According to Iqbal (2002), In Sri Lanka, public services are poor due to politicization [10].

In context of Sri Lanka, public service delivery is very poor in public bureaucracy due to the following public issues: the people do not identify the actual administrator who is responsible for a particular service, people have not awareness on public service delivery and they do not understand the administrator's instructions, administrators also do their works without interesting and lazy, discrimination and unequal treatment, administrators are unfair to deliver the services, they almost concern the people 
who are relatives and friends (favoritism), some administrators are not flexible to the citizens and they follow the rules and regulations harshly.

Similarly, Citizen's Charter is major feature of the better service delivery and good governance. According to Citizens' Charter to Public Service Guarantees: Entitlements to Public Services (2008), this study argue that 'Public Services: Putting peoples first', which means that lasting impact of the Citizens Charter in improving standard of public service provision [8]. Citizen-Client Charter (2007) is a response to the quest for ensuring the three essential aspects of Good Governance: transparency, accountability and responsiveness in delivering public services [2].

The Citizens' Charter displayed standard time for service delivery but service seekers (citizens) were unable to get service within specified period. In Sri Lankan bureaucrats are did not follow the Citizens' Charter. For example, In Sammanthurai Divisional Secretariat Administrative Division displayed the Citizen's Charter, some proving services and required periods are follow: supplying copies of birth, death and marriage certificate-15 minutes, provide certificate for business registration (partnership business)- one day [23]. But, practically service seekers (citizens) did not get above certificates on time. Moreover, according to Damayanthi (2011), 84\% of the respondents in North-Center Province (NCP) and Southern Province (SP) in Sri Lanka were not satisfied with land service delivery. $20 \%$ and $36 \%$ of the respondents in NCP and SP faced negative bureaucratic attitudes [4], such as asking for bribe, favoritism/nepotism of the officials, scolding citizens, not providing customer orient service, asking to come again repeatedly, making delays and hiding documents etc. thus we can say that public bureaucracy and bureaucrats still criticized badly in Sri Lanka.

\subsubsection{Dysfunction of Constitutional Arrangements $\left(13^{\text {th }}\right.$, $17^{\text {th }}$ and $18^{\text {th }}$ Amendments)}

The Provincial Council (PC) system was introduced in Sri Lanka through a constitutional amendment brought in $1987 .{ }^{1}$ It is also being considered as sub-national governments in the Island. The PCs are legislative bodies of the nine Provinces of Sri Lanka. The PCs are usually understood as the branch of government closest to the people, which look after the essential local needs of the community. The theory of democracy, provincial government is the site where more democracy is available to common people at the provincial level which means that provincial government is accepted as the level of government that can facilitate more and better democratic governance in Sri Lanka. The PCs Governor appointed by the president along with higher administrative officers. He is the administrative \& executive head of the PCs. He is empowered to exercise his discretion in the discharge of any function and the Governor's decision is

1 The Thirteenth Amendment (13A) to the Constitution of Sri Lanka is based on the Indo- Sri Lanka Accord which was signed between the Indian Prime Minister Rajiv Gandhi and Sri Lankan President J. R. Jayewardene in July 1978, which incorporated the devolution of powers to provinces. final. And his decision cannot be challenged in a court of law. The all powers and functions are limited with control by the Governor as prescribed in Article 154B in 13th amendment could be exercised by the President directly in person or under his authority by the Secretary to the President. As viewed above, 13th amendment makes governor's control on bureaucracy. The provincial level bureaucracy under control by Governor, he has become a stumbling block to the smooth functioning of the provincial bureaucracy because he has influence all kind of activities like recruitments, transfer, promotion, etc. Thus we can say its major reason for the dysfunction of provincial bureaucracy in Sri Lanka.

The Seventeenth Amendment was introduced in 2001. The main aim of this amendment is to make provisions for the Constitutional Council and Independent Commissions and the depoliticization of public service. Which means that, reduced the powers of the President in regard to making appointments to the higher judiciary, other high posts and the independent commissions. Appointments had to be approved or initiated by a Constitutional Council that was representative of the various political parties and ethnic groups [28]. The Seventeenth Amendment thus provided for a national consensus for appointments to important positions. But, after introduced Eighteenth Amendment, Seventeenth Amendment was abolished. Eighteenth Amendment introduced by President Mahintha Rajapaksa in 2010. The main aim of this amendment is to remove the sentence that mentioned the limit of the re-election of the President. It was centralize all the powers to the executive president. But, again in April 2015, Nineteenth amendment was introduced, it has replacing the defunct $17^{\text {th }}$ Amendment to establish the Independent Commissions and remove the Executive Presidential powers and limit the term of office of the President to five years while the President continue to function as the Head of State, Head of the Cabinet, and Head of Security Forces.

As viewed above constitutional arrangement are major factors of dysfunctions of bureaucracy in Sri Lanka such as 13th amendment makes governor's control on bureaucracy, dysfunctions of 17 th amendment and 18th amendment centralize all the powers to the executive president. Similarly, political purpose, socio-economic context, ineffectiveness of bureaucrats (appointed by political leaders especially high position), and dividing bureaucracy as state and provincial are also core features of dysfunction of bureaucracy.

\subsubsection{Ineffectiveness of Public Service Commission (PSC) and Ombudsman}

The Public Service Commission (PSC) is a main feature of the National Integrity System; it has a critical role in establishing and promoting transparent and accountable governance in Sri Lanka. It has experienced several changes during the post-independence era. At the beginning, the constitutionally mandated PSC played a significant role in managing the public service such as appointment, confirm, promotion, transfer, dismiss and exercise disciplinary control 
over public officers [18]. The main objective of PSC is to establish, improve and sustain the efficiency and effectiveness of the human resource by upholding standards, policies, guidelines and rules governing the appointments, promotions and disciplinary control of the public service (Public Service Commission-Sri Lanka). Now its role is split among several authorities with the periodic constitutional changes such as $17^{\text {th }}$ and $18^{\text {th }}$ Amendments.

This has resulted in the substandard quality in the delivery of state services with increased political interference and influence. It is observed that the higher public officials do not have the required freedom and autonomy to implement the policies to achieve their stated objectives because of political interference in appointments, transfers and promotions. According to Iqbal (2002) argue that, the major reason for the state of the public service is incessant political interference. Besides this, the lack of proper training, dedication, attitudinal orientation, absences of adequate motivation and, last but not least, inadequate remuneration, are contributory factors of dysfunction of PSC [11].

Similarly, according to Public Service and the PSC of Sri Lanka (2014), following are the challenging factors of PSC such as powerless oversight bodies (the president identifies suitable individuals for appointment and seeks the views of the Parliamentary Council that has a majority in it favourable to the president), lack of financial autonomy of the PSC, weak accountability to the legislature, lack of accountability to the citizenry (PSC is considered a 'restricted zone' for citizens. Most citizens are not aware of what and how well the services and functions are performed by the PSC), corruption, lack of uniform central direction [19]. Thus, we can say there is mounting criticism and dissatisfaction among the general public over the lack of responsiveness and accountability of public service delivery and maintenance of law and order in Sri Lanka.

Similarly, the Ombudsman (Parliamentary Commissioner for Administration) was created in 1978 by the Second Republic Constitution. He was created by the constitution to investigate and report (Corporation, Local or Central government institutions) on allegations of infringement of fundamental rights and other injustices by public officers. However, with an amendment to the law in 1994, this fetter was removed and enabled the Ombudsman to receive complaints direct [24]. Consequently, there was a flood of complaints which inundated the Ombudsman's office which was ill equipped to meet such as exigency.

Moreover, many reasons are impact the ineffectiveness Ombudsman such as: the Ombudsman has no branch offices, consequently persons from faraway places have to travel to Colombo to attend inquiries, their expenses for such trips are not reimbursed by the Ombudsman, and he could only inquire into about very few complaints a week and at present has a backlog more than 1000 complaints to be inquired into. All these factors have made the Ombudsman merely as ornament among the administrative institutions in Sri Lanka rather than being a guardian of fundamental rights of state officers.

\subsubsection{Failure and Changing the Public Policies}

Failure and changing the public policies is a next reason to make an issue in dysfunction of bureaucracy in Sri Lanka. One time government introduces a policy and orders to implement, but before the complete implementation, government orders again to stop the policy and introduce another policy. It not only disturbs the bureaucratic but also people are affected by these changes. For example, Colombo Port City Project- 2014, constructed between the southern edge of the new Colombo South Port and the Fort Lighthouse, total area of sea to be reclaimed 450 acres. This project was launched on 17 September 2014 by the former Sri Lankan President Mahinda Rajapaksha and the Chinese President Xi Jinping. This project expected to be completed in 39 months. But, it was suspended by Prime Minister Ranil Wickremesinghe, new Sri Lankan government (existing) in March 2015 [27]. Similarly, local government policy is well and brilliantly formulated. But, it is encountering numerous challenges implementation of policy (especially provincial government) because enormous economic challenges, more political influence on the public bureaucracy (Civil servant), the leadership corruption and ineptitude, and so on.

In Sri Lanka, successive post-independent governments tried to eradicate poverty through introducing policies and specific development plans such a Jana Savia (People's Strength), Samurdhi (Prosperity), and Divi Neguma (Community based Development). The above policies and plans were failed due to wide variety of reasons including lack of inter-organizational communication, fragmented organization, lack of efficient bureaucratic structure, TopDown and Bottom-Up implementation process, lack of governmental commitment, the ineffectiveness of their public bureaucrats, and lack of policy implementation knowledge, and politicization of bureaucracy.

\subsubsection{Politicization and Family Rule of Administration}

Politicization of administration is a global social process bringing a political character; it is high in the developing world. In context of Sri Lanka, Sri Lanka government, ministers and MPs recognized political influence as an essential component of administration and also closer linkages between politicians and officers, political support for appointments, promotions etc. For example, Kachcheri officers (District Secretary) selections had to be examines by government party parliamentarians, though not in the law, Bureaucratic appointments and transfer had to receive parliamentarians' consent. Consequently, first civil servant appointments were routed by qualification, grades, and knowledge but later they are routed through high level politicians.

According to Weber states, 'Authority is principally exemplified within organizations by the process of control'. He has identified three sources of legitimacy authority, namely, traditional (traditional rule: pre industrial period, i.e.: king), charismatic (magical power, i.e.: Mother Theresa, Hitler) and rational legal (invokes the sanction of law, i.e.: elected leaders) [1]. Weber views that rational legal authority 
is codified in bureaucracy (bureaucratic rules must be legalrational has dominated). But, now a day charismatic influence of authority. For example, in context of Sri Lanka, during 2005-2015 Sri Lanka is a country ruled by Mahinda Rajapaksa and brothers, at the apex sits President Mahinda Rajapaksa (2005-2010), his younger brother, Secretary of Defence, Gotabhaya Rajapaksa (2005 -2010), another youngest brother, Basil Rajapaksa, who is minister of economic development, this is more powerful ministry in Sri Lankan history. Another eldest Mahintha Rajapaksa brother Chamal Rajapaksa (70 years old), serves as Speaker of Parliament. Meanwhile, a son of the president, and Namal Rajapaksa, (27 years old), is an MP from the ruling party. This family rule major feature of dysfunction of bureaucracy in Sri Lanka.

\subsubsection{Rural Development and Bureaucracy}

Rural development is a very important feature of development progress in a developing country. Development of the country has to begin from the rural or villages and it depends on the development of its villages. For that every government makes the development policies and gives the authority to the bureaucratic organizations to implement these policies including the grass root citizens [12]. In Sri Lanka, many plans and projects on rural development are made by the government in different periods. And also the bureaucracy of Sri Lanka has the inevitable role in implementing the plans. Generally rural development includes various plans and projects such as community development, health, education, agriculture, infrastructure, women and child care, environmental protection and etc.

In Sri Lanka, Divisional Secretariat, there are various types bureaucrats are working such as Rural Development Officer, Women Development Officer, Cultural Officer, Skill Development Officer, Child Care Officer, Early Childhood Development Officer, Counseling Officer, Child Rights Promoting Officer, Housing Officer, Sports Officer, Agricultural Officer, Industrial Officer and Fishing Officer work in different All their works contribute to achieve the rural development [23]. Divisional Secretariat is being an administrative body, people representatives who speak on behalf of the people at the government level, will not be there. It is a bureaucratic organization and get the permanent staff people cannot claim the equal development. Sometime bureaucrats are unfair to deliver the services. They almost concern the people who are relatives and friends. Some administrators are not flexible to the citizens and they follow the rules and regulations harshly. It makes the people to the negative mind on the bureaucracy and bureaucrats.

\subsubsection{Ethnic, Religious, Regional-Wise Bureaucracy}

Sri Lankan people are very unequal comparison in organizations with the other countries in the global world, especially South Asian region because there are divided to hierarchical arrangements on the based on ethnicity (Sinhalies, Tamil, Muslim), language (Sinhalam and Tamil), regions (Northern, Eastern, other region), symbolic group identity and social class such as: Kandiyan Sinhalese
(Goyigama) Southern Sinhalese (Karave, Durava \& Salagama) Northern Tamil (High level), Eastern Tamils (Low level), Indian Tamils, Muslims, and others. This large ethnic divisions are before independence to until now strongly considers bureaucracy.

For example in 1889 , the number of appointed unofficial members (three Europeans, one Low Country Sinhalese, one Kandyan Sinhalese, one Tamil, one Muslim and one Burgher. Similarly, the distribution of appointment of the Ceylon Civil Service among major ethnic communities was a considerable fact in terms of representative bureaucracy, was highly unequal in relation to the ethnic composition and state bureaucracy in Sri Lanka. For instance, before 1870 to 1946 higher administrative services are appointed by ethnically [9].

Moreover, as far as Northern and Eastern Part administrative offices are concerned, most of the administrator's language is Tamil. As many government seculars and letters received in Sinhala, they have not proper translator so service is not delivered immediately, and it has many procedures and takes a few days. But people who do not understand this, they scold and disturb the bureaucratic. In brief, practically ethnicity and language are major impact in public bureaucracy in Sri Lanka.

\subsubsection{Corruption and Bureaucracy}

Corrupt governance the ultimate destiny of South Asian countries; according to Transparency International's Corruption Perceptions Index in 2015, Sri Lanka was ranked 83th out of 167 countries; Compared to South Asian countries, Afghanistan (166th), Bangladesh (139th), Nepal (130th), Pakistan (117th), India (76th), and Bhutan (27th) [3]. Sri Lanka is the third least corruption rank in the whole of South Asia. According to Peters \& Pierre (2012), corruption and inefficiency are endemic in Bangladesh and Sri Lanka, with nexus between politico-bureaucratic-business elites, busting patron-client relationship and leading to bribery and unethical activities [17]. The Provincial Councils of Sri Lanka, there had been more complaints about corruption. The unsolicited project propositions that have been on the increase in recent times led the politicians and officials to be criticized for abuse and corruption [7].

Similarly, According to Jabes (2005), he was measured corruption (extent of corruption in government officials), bureaucracy quality (autonomy from political pressure), bureaucratic delay (speed and efficiency of civil servant) and red tapism (the degree to which business is free from government unnecessary interventions and delays) in Sri Lanka. Sri Lanka was scored in 3 out of 6 in corruption and bureaucracy quality, which means that moderately clean corruption and moderately bureaucracy quality; Sri Lanka was scored in 6 out of 10 in red tapism which means that Sri Lanka more red tapism country [13]. As viewed above Sri Lanka is a one of the unbiased corrupt country. Thus we can say quality of bureaucracy is poor in Sri Lanka.

\subsubsection{Insufficient Resources and Capacity}

Sri Lanka is a developing country which has to initiates the 
development process with rare resources. In Sri Lanka public offices has got a limited resources including finance. It does not get the enough allocation from the government and does not get it on time. That's why other material resources cannot be obtained in on time. Thus we can say that much public bureaucracy office has faced the trouble to distribute the resources to the people equally.

\subsubsection{Traditional Bureaucracy}

Other issue is the lack of modern facilities. Its buildings and furniture have been broken and there is not enough the technical equipment. It has not the appropriate environment to do the office work. Although e-governance system is spoken in worldwide, there is a traditional way following to deliver the services in public bureaucracy office. Most of the civil servants cannot find solutions to the practical issues. They always emphasize rules and regulations but not the way of solving people's problems.

\section{Way Forward}

As viewed above study, there are many issues impact on dysfunction of bureaucracy in Sri Lanka; these issues are shown as challenges to drive the usual public bureaucracy organizations, so that, the recommendations are proposed below to improving effectiveness, efficiency and SMART (Simple, Moral, Accountable, Responsive, and Transparent) service delivery in public bureaucracy in Sri Lanka.

- Ensuring provincial autonomy decentralization more powers and implements the realistic decentralization as well as cumbersome relationships between central ministries and the field administration (provincial councils) and between the divisional secretaries and local governments (lack of clarity over the accountability relationship of the central, provincial and local governments).

- Ensuring greater communication coordination and accountability between policymakers and service providers (Bureaucrats), policymakers and citizens, citizens and service providers (Bureaucrats) and politicians and bureaucrats.

- Introducing e-government techniques and NPM reform in governance process and also both politicians, bureaucrats and elites should be ready to dedicate and commit for a new era of change (NPM, e-governance, etc.)

- Ensuring higher salary scale/higher salaries in public sector, it may have contributed to better performance in organizations.

- Strengthening stakeholders and citizen participation. Thus, people's representatives should take more concentration about the effective development works in public bureaucracy. As well as if public opinion on public service delivery which are either positive or negative and their suggestions get from the people, it will help to improve the function of public bureaucracy.

- Strengthening the Public Private Partnership (PPP) and
Encourage public and private sector investments.

- Awareness programs should be organized in every level state public bureaucracy office and instruct the people the day to come to the office and bring the documents to get the particular service; that must be given the explanation of the issues in service delivery and its affects.

- Introducing post bureaucratic theory in governance process because it has mesmerized up a change of a new organization reality informed with temporary work system. Therefore, the traditional structure of bureaucracy fails to cope with the new organization reality. Warren Bennis was one of the chief proponents of the post bureaucratic theory. Bureaucracy should followed managerial practice follow as: leaders lead by pulling rather than pushing, by inspiring rather than ordering, from bureaucracy to flexible adhocracy, centralization replaced to decentralization and authority based influence to expertise based influence [1].

- The administrators are should learn and get the training in other languages (Tamil and Sinhala) including English. As well as administrators have to get the IT training ability and make the opportunities to do their work on computer.

- Strengthening the ombudsman and public service commission.

- Ensuring better financial management and accountability.

- Administrators must be flexible when it is necessary for delivering the services to the citizens who are vulnerable.

- Public service is driven by political motivation rather than technical motivation.

- Bureaucrats should be selected by the competitive examination rather than political appointment.

\section{Conclusions}

This study suggests that the survival and dysfunctions of public bureaucracy in Sri Lanka, as well as it tries to find out the solutions which can be used to improve the effectiveness service of bureaucracy in Sri Lanka. Bureaucracy is most important role in the world especially, importance to government and governing process. In contrast, public bureaucracy has earned a nick name for red tapism, nepotism, and corruption. In Sri Lanka, The findings of this study suggest that, in the government of Sri Lanka run through the functions of bureaucracy, it has vital factor in government and governance process in Sri Lanka: implementation of policy, administrative planning, devolution of power, existing institutional arrangement. Administrators played a significant role in the public administration of the country, central, provincial, district, divisional and village level administrative institutions. But in contrast, it has facing many practical challenges: challenges of Public Administration Reforms (PAR), inefficiency and ineffectiveness public service delivery, dysfunction of 
constitutional arrangements, ineffectiveness of Public Service Commission (PSC) and Ombudsman, failure and changing the public policies, politicization and family rule of administration, ethnic, religious, regional vise bureaucracy, insufficient resources and capacity, traditional bureaucracy, lack of citizen participation and lack of awareness of the citizens, corruption, etc. As viewed above, overall public bureaucracy performance and service is low in Sri Lanka. But, Sri Lankan government is taking necessary actions to reduce and resolve the challenges, trying to develop new administration reform, and attempts to increase the efficiency, effectiveness of the of the public service delivery through SMART (Simple, Moral, Accountable, Responsive, and Transparent) concept.

\section{References}

[1] Chakrabarty, B., \& Chand, P., 2012, Public Administration in a Globalizing World Theories and Practices, SAGE Publications India Pvt Ltd, India.

[2] Citizen-Client Charter, 2007, Ministry of Public Administration and Home Affairs, Sri Lanka.

[3] Corruption Perceptions Index, 2015, Transparency International.

[4] Damayanthi, M. N. K., 2011, Devolution versus Deconcentration: A Study on Land Service Delivery System in Sri Lanka, Master in Public Policy and Governance Programme, Department of General and Continuning Education, North South University, Bangladesh.

[5] Dick B., 2003, History of bureaucracy, A brief history of organizations, Available From:

http://www.aral.com.au/DLitt/DLitt_P21whtb.pdf, [Accessed on 18 May 2016].

[6] Economic Commission for Africa, 2003, Public Sector Management Reforms in Africa: Lessons Learned, Addis Ababa, Ethiopia: Development Policy Management Division (DPMD)-Economic Commission for Africa.

[7] Fernando, A., 2013, Politicisation of the Public Service, Available From: http://www.thesundayleader.lk/2013/12/15/politicisation-ofthe-public-service/. [Accessed on 22 May 2016].

[8] From Citizen's Charter to Public Service Guarantees: Entitlements to Public Services, 2008, House of Commons, London: The Stationary Office Limited.

[9] Gunasekara, R., 2016, Representative Bureaucracy: Some Reflections of the Colonial Civil Service Administration in Sri Lanka, Available From:

http://dlib.pdn.ac.lk/bitstream/123456789/1304/1/Tambiah,\%2 0S.\%20J..pdf, [Accessed on 20 May 2016].

[10] Iqbal, M. C. M., 2002, The Public Service of Sri Lanka, Annual Report in the State of Human Rights in Sri Lanka.

[11] Iqbal, M. C. M., 2002, The Public Service of Sri Lanka, Annual Report in the State of Human Rights in Sri Lanka. Available From: http://www.ruleoflawsrilanka.org/resources/writings-ofm-c-m-iqbal/the-public-service-of-sri-lanka, [Accessed on 28 April 2016].
[12] Jabbar, M. A., Sajeetha, T. F., 2015, The Role of Bureaucracy in Building Rural Development: A Study of Addalaichenai Divisional Secretariat, Sri Lanka, Vol. 62, International Letters of Social and Humanistic Sciences.

[13] Jabes, J., 2005, The Role of Public Administration in Alleviating Poverty and Improving Governance: Selected Papers from the Launching Conference of the Network of Asia-Pacific Schools and Institutes of Public Administration and Governance (NAPSIPAG), Asian Development Bank.

[14] Joshi, A., 2011, 4 Important Roles of Bureaucracy in Developing Countries Like India, Available From: http://Www.Preservearticles.Com/201106027410/4-ImportantRoles-Of-Bureaucracy-In-Developing-Countries-LikeIndia.Html, [Accessed on 1 May 2016].

[15] Manivasagar A. V., 2001, Aspects of Public Administration, South Asian Social Science Trust.

[16] Mooney, Knox, Schacht. 2007, The Three Main Sociological Perspectives, Understanding Social Problems, 5th edition, Available from:

https://laulima.hawaii.edu/access/content/user/kfrench/sociolo gy/the $\% 20$ three $\% 20$ main $\% 20$ sociological\%20perspectives.pd f, [Accessed on 25 May 2016].

[17] Peters, G., \& Pierre, J., 2012, The SAGE Handbook of Public Administration, SAGE publication.

[18] Public Service and the Public Service Commission (PSC) of Sri Lanka, 2014, Transparency International Sri Lanka.

[19] Public Service Commission-Sri Lanka, Available From: http://www.psc.gov.lk/web/index.php?option=com_content\&vie $\mathrm{w}=$ frontpage \&Itemid=1\&lang=en, [Accessed on 24 May 2016].

[20] Rathod, P. B., 2007, Comparative Public Administration, ABD PUBLISHERS Jaipur, India.

[21] Sabharwal, M., \& Berman, E. M., (eds), 2013, History and Context of Public Administration in Sri Lanka, Chapter 24, Public Administration in South Asia, CRC Press.

[22] Samaratunge, R., \& Bennington, L., 2002, New Public Management: Challenge for Sri Lanka, Vol 24. No 1, Asian Journal of Public Administration.

[23] Sammanthurai Divisional Secretariat, Available From: http://www.sammanthurai.ds.gov.lk/. [Accessed on 5 May 2016].

[24] The Ombudsman, 2015, The Constitution of the Democratic Socialist Republic of Sri Lanka, Parliament Secretariat.

[25] UNDP, 1999, Decentralization: A Sampling of Definitions, Working paper. New York: UNDP.

[26] Warnapala, W., 2013, Public Administration in Sri Lanka, A Framework for Research, Available From: http://www.island.lk/index.php?page_cat=articledetails\&page $=$ article-details\&code title $=85721 ., \quad$ [Accessed on 20 May 2016].

[27] What's The Deal with Colombo's Port City?, 2016, Available From: http://roar.lk/reports/whats-deal-colombos-port-city/ [Accessed on: 28 April 2016].

[28] Wickramaratne, J., 2014, Constitutional Reform in Sri Lanka: Issues and Prospects, Colombo Telegraph, Available From: https://www.colombotelegraph.com/index.php/constitutionalreform-in-sri-lanka-issues-and-prospects/, [Accessed on 23 May 2016]. 